\title{
ニ, 三の化学反匛に対する非イオン性高分子の添加効果*
}

\author{
折原勝男 ${ }^{* 1} \cdot$ 链口 才二*2 ・松本 昌一*1
}

(受付 1981 年 5 月 1 日 - 霜植終了 1981 年 7 月 13 日)

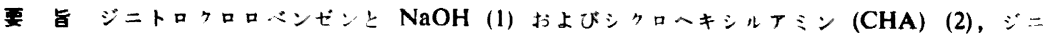
トロフルオロベンゼンと $\mathrm{NaOH}$ (3) 抢よび CHA (4) の水浴没中での反底に对するポリピニルピ ロリドン (PVP) の添加効果を調べた，PVP の添加はいずれの反応をも加速し，その勃果は実弱の 筑囲 $\left(M_{\mathrm{v}}=2.1 \times 10^{4} \sim 200 \times 10^{4}\right)$ では分子 $2.1 \times 10^{4}$ で最大で分子量が增すと低下する，モデル低 分子，N-メチルー2-ピロリドンでは加速斺果ははとんとないことから，効果のピークは $2 \times 10^{4}$ 付近に あるといえる. $[\mathrm{PVP}]=10^{-8} \sim 10^{-2} \mathrm{~mol} / l$ 加ら效果が発現 $し, \sim 0.76 \mathrm{~mol} / l$ まで单調に增加する. 加 速効果の大ききは (1)》(3)，(4)，(2) の順である。エタ,ールの添加で刘果が低下するので, PVP

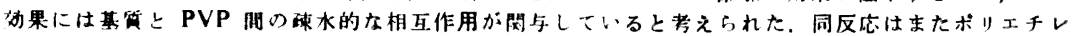
ングリコールによっても加速され，ボリピニルナルコールに上っては減速される。
\end{abstract}

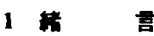

トリフェニル×タン (TPM) 系色秦のフルカリ水溶液 中での退色反底に対し，非イオン性水流液性高分子，ポ リピニルピロリドン (PVP)，ポリエチレングリコール (PEG) がかなり大きな加速效果を示すことを報告し だ、特に效果の大きいPVP について，夷験室合成の 各種分子量物を使い，加速勃果か：PVP の分子量に大き く依存することを見いたしだ．この反底では，加速奶 果の発現はカチオン性基質の䂾水性部分と PVP ニニッ ト中の涑本性基との㻋水性相互作用，65一つの反応基 質 $\mathrm{NaOH}$ と PVP ニニット中の極性部位のイオンー双極 子相互作用により，両基質か：PVP 鎖に引号へられて 局所的に满縮するためであろらと考えた。

このときの反応はカチオンレフニオンのそれである. これに対し，ノニオンとフニオン，あるいはノニオンと ノニオンの反沁では反基質と PVP およびその他の非 イオン性高分子との䞒の相互作用が变化し添加効果す異 なることが予想される. 今回は $\mathbf{A}+\mathbf{B} \rightarrow$ の反応で， $\mathbf{A}$ して非イオン性で踈水性基を持つジニトロクロロペンゼ ン(DNCB) およびジニトロフルオロペンゼン (DNFB), Bとしてイオン性の $\mathrm{NaOH}$ および非イオン性で眯水性 基を持つシクロヘキシルアミン (CHA) を選んで, こ れに対する PVP, PEG およびポリビニルフルコール

\footnotetext{
*本研究を「水浴液中の化学反匛に対する非イオン性 水溶性高分子の共存効果第3 報」とする。

*1 山形大学工学部 ( 992 米沢市城南 4-3-16)

*2 オーミケンシ(姝) (-503 大坦市林町 6-80)
}

(PVA) の水溶没系での添加初果を淍くた。

DNCB，DNFB と NaOH あるいはフニリンの反応に 対する界面活性剂 : セルの效果は Buntonと Robinson

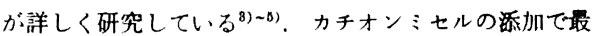
大 80 倍の加速, ノニオンミセルではわずかに加速, 厂 ニオンミセルでは減速あるいはわずかの加速効果が見出

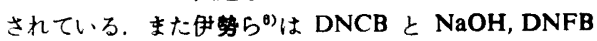
とナニリンとの反纫が柾水性基を持つ高分子電解質に上 ってもかなり大きく加速されることを見いたしててる. いずれす加速効果の原因として， ミセルあるいは高分子 電解質の強い疎木性书よびカチオンの場合を指摘し、ま た反応の活性化ェンタルビーの減少を見いだしている． ๖らに Blandamer と Reid") は DNCB と $\mathrm{NaOH}$ と の反纪対するカチオンミセルの加速效果を考察し, 水

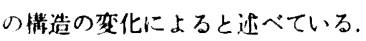

ノニナンミセルでは加速奻果が見いだされないことか ら，ノニオンの高分子でる同槏に加速効果はないと子想 される. しかし，基質の眯水性部と，ノニオン高分子の 䟱水性基，また基質の極性部あるいはイオン部分とノ二 オン高分子の極性基との閒にそれぞれ引きつけの相互作 用が有効に㗢けば，TPM 系色素のフルカリ退色反応の 場合 ${ }^{1), 2)}$ 之同様, 加速効果の発現が期待されてよいと考 えられる. 夷䖋を陚みた結果，加速勃果を見いたした。 ここではこの結果とさらに PVPによる加速效果におけ る高分子の浱度, 分子量および反応基賀の種類による影 即などの検討結果を垠告する。 


\section{2 英}

\section{1 反応基再}

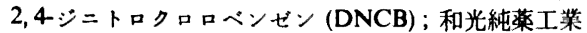
(株) 製特級品, 2,4ジニトロフルオロペンゼン(DNFB); イーストマンコダック社製特級品をそれぞれシリカゲル 上に保存しそのまま用いた。

水酸化ナトリウムは関東化学楽品(株)製特級品を, シ クロヘキシルフミン (CHA) は和光純祭工業(株)製特級 品をそのまま用いた。

\section{2 ボリマー}

(B)-K90；キシダ化学桼品(株)から入手した PVPK 90 を第 2 報と同じ方法で精製して用いた，Cerney ら 粘度式で求めた分子量は $M_{v}=140 \times 10^{4}$ である. 凹-K 30; 和光純雬工業(株)から入手した PVPK 30 の水溶 液を 50 倍量のアセトンで沈殿する.この再沈操作を 4 回繰り返した．このあと常温で咸压乾燥した． $M_{\mathbf{v}}=4.4$ $\times 10^{4}$ である ${ }^{8}$ ． PEG; 和光純薬工栄(株)製一級品をそ のまま用いた。メーカー表示分子量は 300. PVA：(株) クラレ製ポバール（完全けん化物）をソックスレー抽惊 器でメタノールにより 20 時間精製し，このあと室温で 减圧乾嬠して用いた。メーカ一表示重合度 500 . 実験宝 合成 PVP; メタノールを溶媒としてフゾビスインブチ ロニトリルを開始郕に用い $N$-ビニル-2-ピロリドン (NV2P) を重合した．前報2)で調製したものと同一物で ある. モデル低分子物；モノマー(NV2P)， $\alpha$-ピロリド

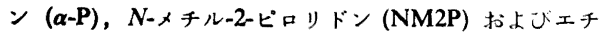
レングリコール (EG) を用いた. 前 3 者は和光純薬工業 (株)製一級品を，EG は同社製特級品を，いずれす减压 蒸留により精製して用いた。

\section{3 反応沿媒}

反応溶媒はイオン交換水を用いた，反応への添加物と してェチルフルコール，和光純䓝工彩(株)製特級品，を 蒸留精製して用いた。

\section{4 反応およひ速度定数の测定}

反応は次の四つについて行った。

$$
\begin{aligned}
& \mathrm{O} 2 \mathrm{~N} \underset{\mathrm{NO}_{2}}{\mathrm{C} l}+\mathrm{NaOH} \rightarrow \mathrm{O}_{2} \mathrm{~N} \underset{\mathrm{NO}_{2}}{\mathrm{O}} \mathrm{OH}+\mathrm{NaCl} \text { (1) } \\
& \mathrm{O} 2 \mathrm{~N} \underset{\mathrm{NO}_{2}}{\mathrm{Cl}}+\mathrm{H}_{2} \mathrm{~N} \mathrm{O} \rightarrow \mathrm{O}_{2} \mathrm{~N} \underset{\mathrm{NO}_{2}}{\mathrm{O}} \mathrm{O} \mathrm{O}+\mathrm{HCl} \\
& \mathrm{O} N \underset{\mathrm{NO}_{2}}{\mathrm{O}}+\mathrm{NaOH} \rightarrow \mathrm{O}_{2} \mathrm{~N} \underset{\mathrm{NO}_{2}}{\mathrm{O}} \mathrm{OH}+\mathrm{NaF} \\
& \mathrm{O}_{2} \mathrm{~N} \underset{\mathrm{NO}_{2}}{(\mathrm{O})}+\mathrm{H}_{2} \mathrm{~N} \mathrm{O} \rightarrow \mathrm{O}_{2} \mathrm{~N} \underset{\mathrm{NO}_{2}}{\mathrm{~N}} \mathrm{O}
\end{aligned}
$$

(1)〜 (4) 共に DNCB および DNFBに対してNaOH, CHA の隻度を大過翻とし，擬一次反応で取り报えるよ らにした，反応基質，ボリマーの各水溶液をあらかじめ 淮備し， $25^{\circ} \mathrm{C}$ に保っておく，基質 $\mathrm{A}$ とポリマー溶液の

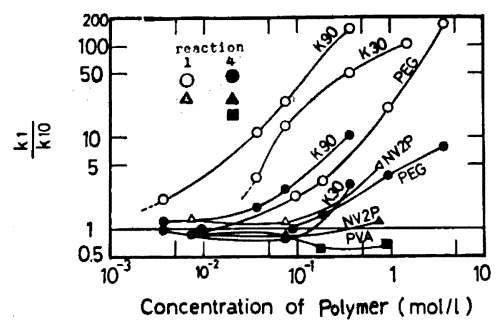

Fig. 1. Effects of the concentration of polymers on the reactions, (1) and (4), in aqueous solution at $25^{\circ} \mathrm{C}$.

$[D N C B]=1.0 \times 10^{-4} \mathrm{~mol} / l$,

$[D N F B]=4.9 \times 10^{-3} \mathrm{~mol} / l$,

$[\mathrm{NaOH}]=8.3 \times 10^{-3} \mathrm{~mol} / l$,

$[\mathrm{CHA}]^{-5.0} \cdot 10^{-3} \mathrm{~mol} / \mathrm{l}$.

所定留を武験管内で语含し， $25^{\circ} \mathrm{C}$ の恒温水槽に入れて おく。これに同温度に保っておいた基質 Bである $\mathrm{NaOH}$

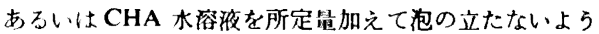
にかくはんし，反伈開始とする，反応液を石英セルに移 し， $25^{\circ} \mathrm{C}$ に調整しておいた分光器のセルホルダーに七 ットし, 吸光度の增加を読んた。，吸光度の湘定は(株) 日 立製作所製 100-10 型シングルビーム分光光度計を使用 し，生成物であるジニトロフェノールまたは 2,4ジ二 トロフェニルシクローキシルアミンのそれぞれの最大吸 收波拉 $360 \mathrm{~nm}, 365 \mathrm{~nm}$ に打外る吸兆度变化を読んた。 别に 2,4-シニトロフェノール扰よび 2,4ジニトロフェ ニルシクロへキシルアミンの相当浱度の溶液を調製し て, その吸炕度をすって $100 \%$ 反応時の值とした。これ 上りボリマー添加時 および 無添加時の 擬一次速度定数 $k_{1}$ および $k_{10}$ を求め， $k_{1} / k_{10}$ の做によりポリマー添加 効果を評体した。

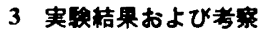

\section{1 二, 三の水溶性高分子の添加効果}

反応 (1) と (4) に対する市販の PVP, PEG, PVA の添加効果を Fig. 1 に示す. PVP と PEG は反応を 加速し，それぞれの効果は高分子の濃度とともに增す. PVA の添加ではわずかに減速する. また PVP に比べ PEG の矨果はかなり高湌度域で起こる，以上の傾向は TPM 系色秦のアルカリ退色反応に対する同じボリマー の添加効果と似いる. PVP のモデル低分子物， NV2P の添加では高祳度域で加速はするがその程度は小さい. また PVP, PEG 共に反応 (1) に対する加速効果は 100 倍以上に達するが，反応（4）に対しては数倍〜10 倍に すぎない。

以下に比的低渡度で大きな加速效果を発現する 


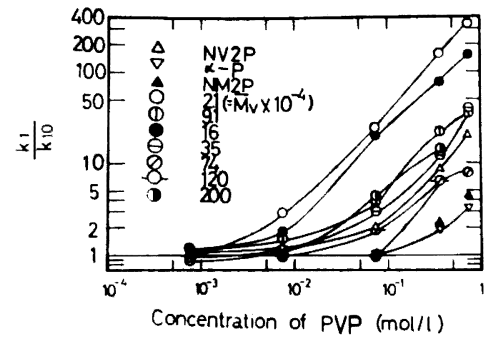

Fig. 2. Effect of PVP concentration on the reaction (1) in aqueous solution at $25 \mathrm{C}$. [DNCB] $=1.0 \times 10^{-4} \mathrm{~mol} / l$, $[\mathrm{NaOH}]=8.3 \times 10^{-3} \mathrm{~mol} / l$.

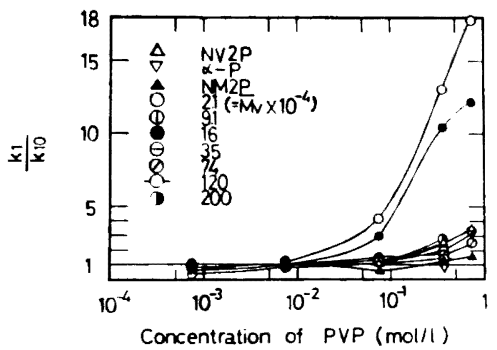

Fig. 3. Effect of PVP concentration on the reaction (4) in aqueous solution at $25^{\circ} \mathrm{C}$. $[D N F B]=4.9 \times 10^{-5} \mathrm{~mol} / l$, $[\mathrm{CHA}]=5.0 \times 10^{-8} \mathrm{~mol} / \mathrm{l}$.

\section{PVP の添加について述べる.}

\subsection{PVP 湿度の影雾}

市販 PVPを用いた Fig. 1 の結果は (1-K90 の方 が 円-K30 より大きい効果を示す。しかしなからら市眅の PVP では同じ分子量物でる入手先により効果が異なる ことを TPM 系色素の反沁で経験しており2)，Fig. 1の 結果を分子量による効果の差と断定することはできな い. 市眅品では製造条件が不明なので, 前報2)で调製し た実験室合成の各種分子量の PVP を用い実験した。

Fig. 2 および Fig. 3 にそれぞれ反応 (1) と反応 (4) に対する各種分子量の PVP 添加効果を PVP 浱度に対 してプットした．両因を比較すると，どの分子量物に ついてす同一 PVP 浱度で, 反応 (1) の方が (4) より す 10 倍あるいはそれ以上加速効果は大きい，このこと は市販 PVP についての Fig. 1 の結果と同様である.

PVP による加速効果の PVP 港度依存性には次の二 つの事実が認められる.（イ）効果の発現し始める PVP 漕度は反応（1）では $10^{-8} \sim 10^{-2} \mathrm{~mol} / l$ であるのに対し

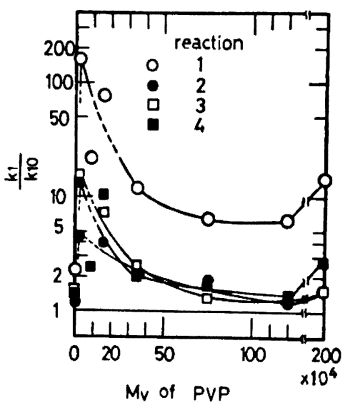

Fig. 4. The dependence of the acceleration effect on the molecular weight of PVP at $25^{\circ} \mathrm{C}$. [DNCB] $=1.0 \times 10^{-4} \mathrm{~mol} / 1$, [DNFB] $=4,9 \times 10^{-5} \mathrm{~mol} / 1$. $[\mathrm{NaOH}]-8.3 \times 10^{-3} \mathrm{~mol} / \mathrm{l}$, $[\mathrm{CHA}]-5.0 \cdot 10^{-3} \mathrm{~mol} / \mathrm{l}$, [PVP] $0.38 \mathrm{~mol} / 1$.

て, 反応 (4) では $10^{-2} \sim 10^{-1} \mathrm{~mol} / l$ とほぼ1けた大き い.ま PVP の同一㳻度で比べた加速効果が大きい系 ほどより低溒度から効果が発現する。これは前に報告し た CV，EV のアルカリ退色反応への PVP 效果の場

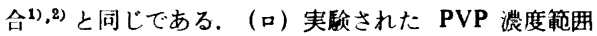
$(\sim 0.76 \mathrm{~mol} / l)$ では加速効果は PVP 浱度とともに一 梯に增し, 前報の CV，EV の反応で見られたような， あるPVP 淟度で極大を示し，より高い搌度で効果が減 少するよらなことは観測されない，CV，EV の反応の 場合です $\mathrm{NaOH}$ の濃度を高めると加速効果の極大は PVP の高丧度側に移動し, 遂に実駼の浱度範囲では現 れなくなる.この現象の理由については前報で考察した のでここでは省略する. 本实臨では基質 DNCB，DNFB の浱度は前報の $\mathrm{CV}, \mathrm{EV}$ の濃度に比べて 5 10 倍大き く, $\mathrm{NaOH}, \mathrm{CHA}$ の洤度も前報の $\mathrm{NaOH}$ 濃度に比へ て若干大きい, そのため加速効果の PVP 䈨度依存性に 極大が現れ寸濃度とともに上年したと考えられる。

\subsection{PVP 分子鼻の影暨}

Fig. 4 に反応 (1)，(2)，(3)，(4) に対するPVPの 添加劫果を PVP の分子量に対してブロットした. PVP 浱度は $0.38 \mathrm{~mol} / l$ で一定である. どの反応に拈いても モデル低分子，NM2P では加速効果はきわめて小さく， 分子量 2 万付近のポリマーで大きい加速効果が現れ, 更 に分子量を增すと, 塊状重合物の分子量 200 万の結果は 別として, 効果は漸减する. この理由は前報で詳しく述 ベたように2)，反応基質の引きつけには，引きつける働 きをなす基, すなわち䟱水基および極性基のある程度の 連続が必要であり, ある程度斬続して始めて高分子効果 
Table 1. Influence of $\mathrm{EtOH}$ to the reaction (4) in the presence of PVP in aqueous solution at $25 \mathrm{C}^{\text {n) }}$

\begin{tabular}{cccc}
\hline \hline $\begin{array}{c}\text { Ethanol } \\
(\mathrm{v} / \mathrm{v} \%)\end{array}$ & $\begin{array}{c}\text { PVP }\left(M_{\mathrm{v}}=16 \cdot 10^{4}\right) \\
(\mathrm{mol} / l)\end{array}$ & $\begin{array}{c}k_{1} \times 10^{4} \\
\left(\mathrm{~s}^{-1}\right)\end{array}$ & $k_{1} / k_{10}$ \\
\hline 0 & 0 & 5.01 & 8.2 \\
0 & 0.76 & 41.3 & \\
20 & 0 & 5.25 & 5.3 \\
20 & 0.76 & 28.0 & \\
40 & 0 & 6.96 & 2.6 \\
40 & 0.76 & 18.4 & \\
\hline
\end{tabular}

a) $[\mathrm{DNFB}]=4.9 \times 10^{-5} \mathrm{~mol} / l,[\mathrm{CHA}]=5.0 \cdot 10^{-3}$ $\mathrm{mol} / \mathrm{l}$.

として加速効果が発現する.しかし高分子の速鎖が長く なりナぎると高分子のコイル中に多くの浴媒(水)が取り 込まれるので, コイル内に引き込束れた基質峘度は減少 し、加速好果が低下寸るものと考えられる。

\section{4 反応基算と PVP 効果}

Fig. 4 によると PVP に上る加速效果の反応に上る 順 $/ 5$ (1)》(3)，(4)，(2) である. Fig. 4 で反応 (1) と（3）の場台 $[\mathrm{NaOH}]$ は共に $8.3 \times 10^{-3} \mathrm{~mol} / \mathrm{l}$ である が [DNCB] は [DNFB] の約 2 倍である. 前報で遮べ た5に反纪系の基質浱度が小さい方が加速効果は大きい ことを考虑すると, [DNCB] と [DNFB] が同一浱度で あればー畨 (1)》(3) である. Buntonと Robinson ${ }^{3), 4)}$ による两反応に対するカチオンミセルの実驗結果は, $[D N C B]=1.0 \times 10^{4} \mathrm{~mol} / l,[D N F B]=1.0 \times 10^{-8} \mathrm{~mol} / l$, $[\mathrm{NaOH}]=0.01 \mathrm{~mol} / l$ で, 加速効果 $k_{2} / k_{20}$ はそれぞれ 最大で約 80 倍および 60 倍であり，PVP の昭合と似 た傾向を示す. PVP 無添加系での DNCB, DNFB と $\mathrm{NaOH}$ の反纫の擬一次速度定数はそれぞれ $8.9 \times 10^{-7}$ $\mathrm{s}^{-1}, 1.4 \times 10^{-8} \mathrm{~s}^{-1}$ であり DNFB の反応の方が $10^{3}$ 倍 以上大きいこれは $\mathrm{Cl}$ と $\mathrm{F}$ が結合している炭慗原了. の求電子性の強さの差によるとして解积できる. DNCB, DNFB 其に柾水性に大きな美はなくPVP 加速效果が DNCB の方が DNFB より大きいのは DNCB, DNFB のPVPとの閒の虂性相互作用の差によるか，または相 互作用の結果就導される分極性の美に基つく反応性の变 化によることが考えられるが，晛時点で詳縕は明らかで ない.

$\mathrm{NaOH}$ との反応に比べて CHA との反応 (2) および (4) の加速効果が小さいのは CHA の蹯水性のためと考 えられる. 柾水性基質と $\mathrm{NaOH}$ との反応では䟱水性基 質はPVP の眯水性部に, $\mathrm{NaOH}$ は PVP の極性部に 引きつけられて加速される。 CHA との反応の場合, CHA は柾水性基質と同じく PVP の䟱水部に引きつけ られて, 眯水性基質, CHA 共に同じ結合座位に引きつ けられるため相互に引きつけを妨害することになる。こ
のため两反応基共に PVP 鎖近傍での局所的な濃縮性が 低下し， $\mathrm{NaOH}$ との反応の場合に比へて加速効果が小 さくなるすのと考えられる.

\section{5 エタノール添加の影箱}

以上で述へたように，本報告で取り上げた（1)〜 (4) の反応に対するPVP の加速㹝果は前報で述べた CV, EV の $\mathrm{NaOH}$ 水溶将中での退色反店への PVP の加速 刘果に似ており，水容液内でそれぞれの反応基が PVP に引きつけられ局所的に浱樎されて反応が加速されたと 寸ると考えやすい，PVP 入基質が引きつけられる原因 として瑓水性相互作用が考えられる。この場合, 反応系 :二水の满造を破壤するアルコールを添加すれば，蹯水性 相互作用は低下し，さらに反応の加速も低下するであろ う.たとえば反応 (1) およびDNFB とアニリンの水系 の反応ではカチオンミセル7) あるいは蹯水基をるつ高分 子電解翼の)の加速奻果がェタ人ール添加で低下すること が報告されている，そこで反応(4)について，PVP 添 加と無添加の両系にエタノールを添加して PVP の加速 扮果の変化を晭へた. Table 1 に結果を示す. PVPな しの系てはェ夕ノール分积の增加につれて速度定数は大 きくなるか，PVP 添加系では逆に小さくなる。この結 果, エタノール分率を $0 \rightarrow 20 \rightarrow 40 \%$ と增すにつれて, PVP の加速动果 $\left(k_{1} / k_{10}\right)$ は 8.2 $\rightarrow 5.3 \rightarrow 2.6$ 倍と減少し てゆく、これから柾水性相互作用によるPVPへの基質 の引きつけが加速勃果に笴与していると考えられる。

$$
4 \text { まとめ }
$$

反応（1）および (4) に対する市販のPVP およびそ の他のノニオン性水溶性高分子の添加効果を调べ, PVP, PEG の共存によりどの反応も加速され，PVA では減

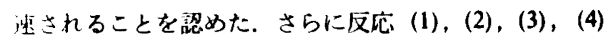
について, 奏験窒重合の PVP $\left(M_{v}=2.1 \times 10^{4} \sim 200 \times\right.$ 104)を用いて，加速効果の PVP 湌度ならびに分子量の 影然を検部した，象駺の籁囲，[PVP] $\leq 0.76 \mathrm{~mol} / l$, で

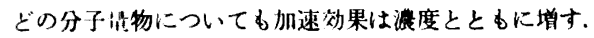
またPVP 分子量 2 万付近で最大をとるよ5な分子裂作 存性を示す，PVP のモデル低分子物による刘果はきわ めて小さいことから，加速效果の発現にはニニットのあ る程度以上の速鎖が必要であることがわかる，これらの 結韯は反応 (1)〜 (4) に共通であり, さらに前報2)で述 べた TPM 系色素のフルカリ退色反応の場合とほとんど 同傾向である. 効果の程度は反応の種類，すなわち基質 の種類により異なる. 同一の PVP 漕度では (1)》(3), (4)，(2)の順である，反応基質についていえばDNCB> DNFB および $\mathrm{NaOH}>\mathrm{CHA}$ である.

PVP を添加した系にさらにェタノーを加えるとPVP の加速効果が減少する．このことから PVP 効果の発現 には反応基貿と PVP 間の眯水性相互作用が重要な役割 


\section{$\therefore$ 三丨化学反吉に对する非イオン性高分子の添加效果}

を果たしていると侤えられる.

\section{文嗝}

1) 松本昌一，折原勝男，满分子踚文篹，36，1-6 (1979).

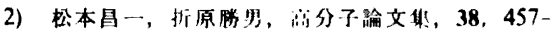
463 (1981).

3) C. A. Bunton and L. Robinson, J. Am. Chem. Soc., 90, 5972-5979 (1968).

4) C. A. Bunton and L. Robinson, J. Org. Chem.,
34, 780-785 (1969)

5) C. A. Bunton and L. Robinson, J. Am. Chem. Soc., 92, 356-361 (1970).

6) T. Ueda, S. Harada, and N. Ise, Polym. J., 6, 473-479 (1974).

7) M. J. Blandamer and D. J. Reid, J. Chem. Soc., Faraday Trans., 1 (71), 2156-2160 (1975).

8) L. C. Cerney, T. E. Helminiak, and J. F. Meier, J. Polym. Sci., 44, 539 (1960).

Nonionic Polymer Effects on the Reactions of 2,4-Dinitrochlorobenzene and 2,4-Dinitrofluorobenzene with Hydroxide Ion and Cyclohexylamine*

Katsuo OriHarA*1, Saiji Hiouchi*2, and Masakazu Matsumoto*1

*Studies on Effects of Nonionic Water-Soluble Polymers for Aqueous Chemical Reactions. III.

*1Department of Textile and Polymer Technology, Faculty of Engineering, Yamagata University (3-16, Jonan 4chome, Yonezawa, 992 Japan)

*2Omi Kenshi Co. Lid. (6-18, Hayashi cho, Ogaki, 503 Japan)

The effects of poly(vinylpyrrolidone) (PVP) on the reactions of 2,4-dinitrochlorobenzene with $\mathrm{NaOH}(1)$ and with cyclohexylamine(2), and of 2,4-dinitrofluorobenzene with $\mathrm{NaOH}(3)$ and with cyclohexylamine(4) were studied. PVP enhances all the reactions, and the enhancement depends upon the concentration and the molecular weight of PVP. In the range of molecular weight of PVP examined, $2.1 \sim 200 \times 10^{4}$, the enhancement is the highest at $M_{0}=2.1 \times 10^{4}$, then it decreases gradually with an increase of the molecular weight. Since $N$-methyl2-pyrrolidone, a model compound of PVP unit, exhibits little enhancement, the maximum enhancement must lie in the neighbourhood of the molecular weight $2.1 \times 10^{4}$. The enhancement becomes substantial from the concentration, $10^{-8} \sim 10^{-2} \mathrm{~mol} / l$, and increases with the concentration up to $0.76 \mathrm{~mol} / l$, the highest concentration examined. The order of the enhancement in the four reactions is (1) $\gg(3),(4),(2)$. When ethanol is added to the reaction (4) system, the effect of PVP is subdued. This supports that the hydrophobic interaction between the substrate and the polymer chain is a factor of the enhancement. The above four reactions are also accelerated by poly(ethylene glycol), but decelerated by poly(vinyl aclohol).

KEY WORDS 2,4-Dinitrochlorobenzene / 2,4-Dinitrofluorobenzene / Reaction in Aqueous Solution / Poly(vinylpyrrolidone) / Poly(ethylene glycol) / Poly(vinyl alcohol) / Polymer Effect / Molecular Weight / Hydrophobic Interaction /

(Received May 1, 1981 : Accepted July 13, 1981)

[Kobunshi Ronbunshu, 38 (11), 769-773/1981)] 